\title{
IN TRANSIT: SEARCHING FOR A SENSE OF 'PLACE'
}

\section{Tom Voyce}

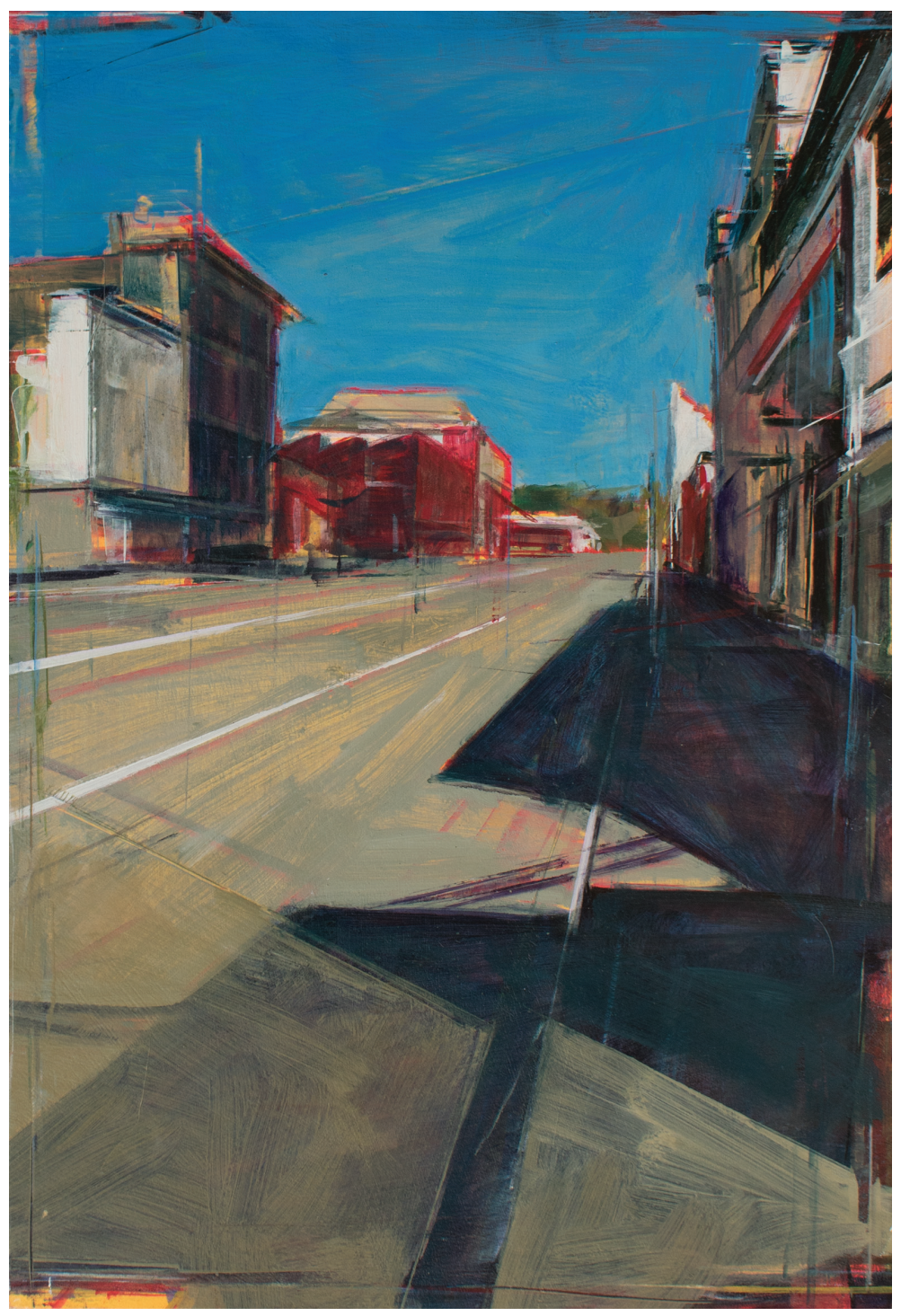

Figure I. Tom Voyce, High Street, Dunedin, 20 I 8, oil on board, $40 \times 27 \mathrm{~cm}$. 
In this report, I present an overview of my artistic process and my residency at the Dunedin School of Art in September and October 2018. Seeking to build on previous bodies of work that explore the subject of place, I arrived in Dunedin, having travelled from the UK via Canada, the US and Fiji. Over the course of five weeks' travel, I had built up a body of preparatory drawings, colour studies, written notes and photographs that recorded my transition from place to place. I would go on to use this information to inform my studio practice on arrival in Dunedin. While the great contrast of landscapes, cityscapes and skyscapes all excited my artistic eye, I always found myself drawn to certain fundamental concerns that, in recent years, have become essential features of my artistic approach: perspective, composition and a contrast of light.

\section{BEGINNINGS}

While an undergraduate student, I became intrigued with the work of the mid-twentieth-century painter Edward Hopper. His atmospheric, cinematic scenes caught my imagination. His uneasy

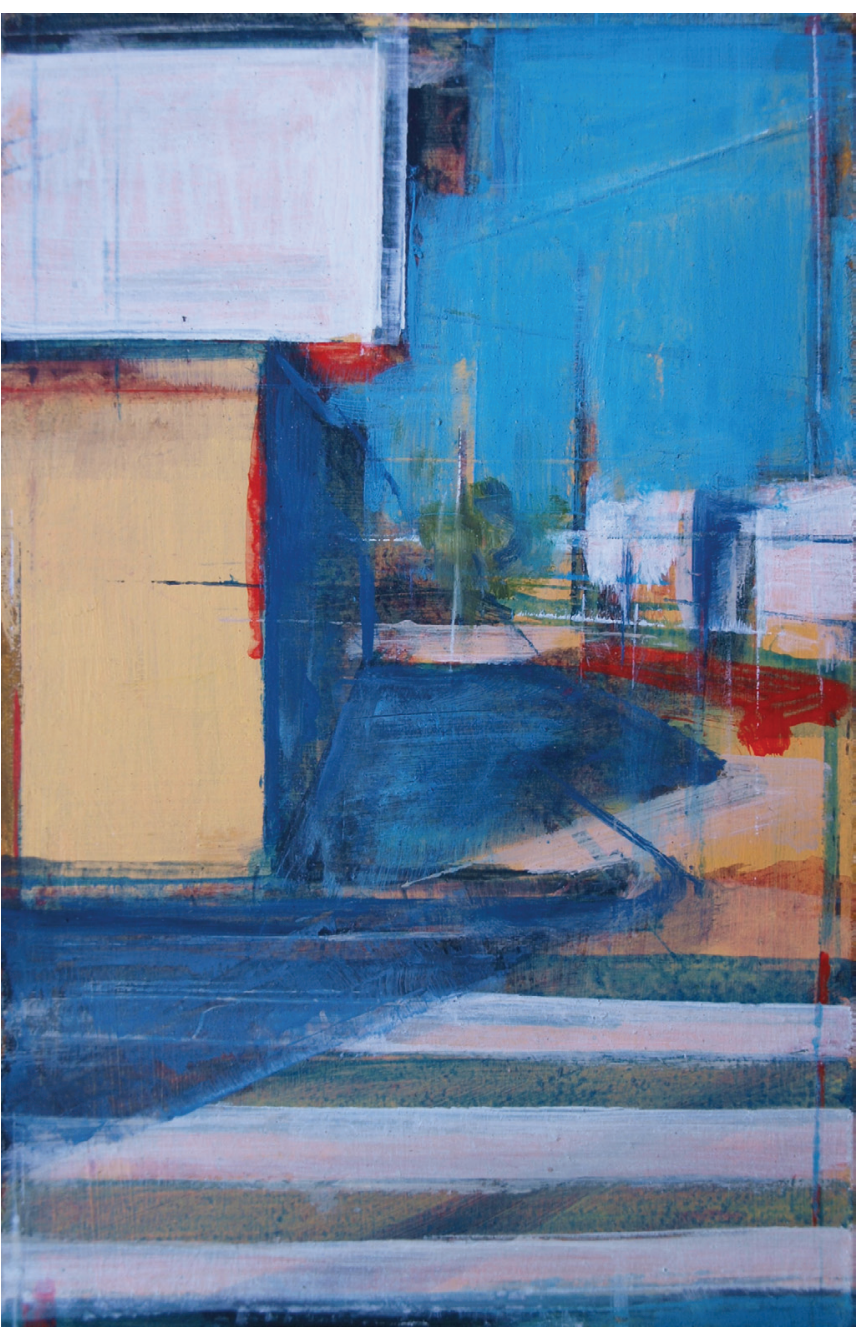

Figure 2. Tom Voyce, Bay Area Street View, 2016 , oil on board, $13 \times 9.7 \mathrm{~cm}$.

yet beautiful and insightful compositions made me appreciate colour and the beauty of light. His work supplemented an already growing interest in mid-twentieth-century American history around the time of the Great Depression and the lead-up to the Second World War. It seemed an age of innocence, yet intense hardship. The cinematic appeal of his work reflects a sense of unease and loneliness, the feeling that something unsaid is happening.' Hopper's work went on to influence many artists and creative people - for example, filmmaker Alfred Hitchcock and New Zealand landscape painter Graham Sydney.

Despite refusing to allow his work to be categorised as part of the new popular movement associated with the abstract expressionists in the 1940s and '50s, there is a clear nod to a sense of the abstract in some of Hopper's later paintings. I often found myself transcribing his pieces in order to understand the sense of silent tension and intrigue that they convey, but then also begin to abstract them. This was the first time that I found myself exploring the boundaries around this genre of painting. 


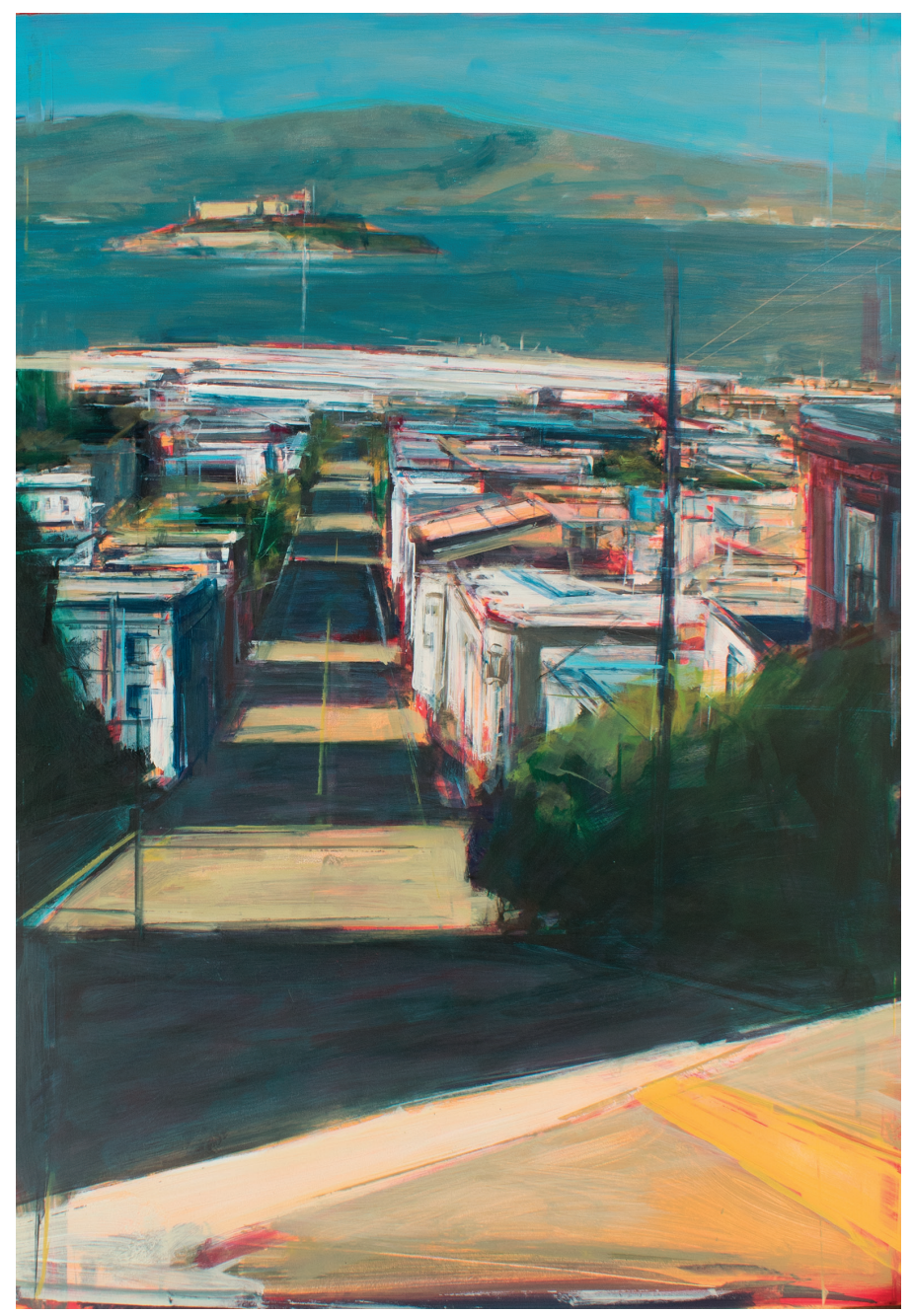

Figure 3. Tom Voyce, View of the Bay, San Francisco, 2019 , oil on board, $80 \times 55 \mathrm{~cm}$.
Modern abstraction began in the nineteenth century with artists such as JMW Turner and James McNeil Whistler, and expanded later with the impressionists, but it was Henri Matisse who demonstrated how painting could depict the essence of a place while also pushing the boundaries between composition, shape and colour, as shown in his French Window at Collioure, $1914 .^{2}$

Decades later, throughout the 1940s and '50s a large number of artists began to change the path of modern art as New York overtook Paris in the postwar years to lead the way in artistic trends. Abstract expressionism, as it became known, has since been seen as a quintessentially American movement, but arguably the artists at its centre came to the United States from across the oceans, predominantly from an increasingly troubled Europe. Artists such as Mark Rothko brought with them a wealth of new ideas and beliefs including the aesthetic of a new, purer way of mark-making that defined a whole new era of painting. This movement shook the foundations of modern art as it was taken up by a new generation of artists who began to demonstrate how painting could become the subject itself, believing that artistic expression is "drawn from an inborn feeling for form; the ideal lies in the spontaneity, simplicity and directness of children."3

Richard Diebenkorn (1920-1993), a contemporary of these abstract expressionists, was a modern painter of extraordinary intellegence and sensitivity who quiety constructed a place for himself in the history of twentieth century art with his singular vision and powerful commitment to the idea of practicing both figuration and abstraction. ${ }^{4}$ Informed mostly by the landscape of California and the West Coast, but also by interiors and in some cases the human form, Diebenkorn was a painter of uncommon stature who was situated firmly within the ethos of American modernism. ${ }^{5}$ But for the first seven years of his professional life, Diebenkorn's practice reflected the same vocabulary as his peers - abstraction. Thus many observers were shocked when, in 1955, he made a sudden shift to a representational mode. ${ }^{6}$ 
Diebenkorn's influences hark back to the founders of what became modernism in painting, in particular Mattisse. He was, however, also drawn to the work of Edward Hopper by his teacher Daniel Mendelowitz and, after graduating from the California school of Fine Arts (CSFA) in San Francisco (now known as the San Francisco Art Institute), Diebenkorn developed a rigorous abstract style influenced by the likes of Clifford Still and Wilhem de Kooning. He began teaching and then returned to the Bay Area, where he worked in a more representational style alongside other artists, becoming part of what was later known as the Bay Area Figurative Movement. His subject matter at the time included interiors, still lifes, landscapes and the human form.

This style persisted for much of the 1950's and 60's as Diebenkorn explored places where he worked or visited, such as Albuquerque and Berkeley. But after seeing a Matisse show in Los Angeles in 1966, his work took a massive shift back to abstraction. It is difficult not to ascribe enormous weight to this experience for the direction his work took from then on. ${ }^{7}$ A year later he began his famous Ocean Park series. ${ }^{8}$

It was my own interest in the depiction and exploration of place that originally drew me to Diebenkorn's work. I was not initially appreciative of his later Ocean Park series, prefering his earlier figurative studies from around the Bay Area, in particular Cityscape 1. 'It was at my Bachelors degree show that I produced a series of oil-on-canvas works based on a single location, a small housing estate in my university town of Aberystwyth, an estate that reminded me greatly of my home, both having been built in the 1970s in the same style. They seemed to hold the warm light of evening - a feature that I always noticed, but which was never apparent in my own work from this period. The focus on the 'silent theatre' of a composition in my work reflected my interest in Edward Hopper, whose work had a powerful hold over me at that time and with whom "picture after picture portrays that inescapable silence."'

During my Master's degree, I continued to explore the subject of place - often areas void of people, featuring hard-edged, human structures which were built into the landscape. My Dovey Junction series explored the isolation of both the artist and the subject matter of an image. The junction is an isolated place, a platform that seemed to serve no purpose, visited only so often by a train, with people never getting off or on and the train disappearing into the distance. Hopper's works portraying lonely figures - paintings and etchings of both landscapes and urban areas - are equally powerful when the human element is removed.

I have always had an interest in travel and journeys. I have explored this often in smaller projects in the past and it has continued to be a element that has influenced my work. I decided to use this subject as the basis for a body of work for my Master's show. My aim was to produce small, semi-abstract studies in watercolour while travelling, which I could then refer to when back in the studio. Influenced by Diebenkorn, these paintings would show a balance between the abstract and the figurative and were done at speed in order to retain the energetic brushwork that I found to be exciting. When back in the studio, these studies would be used as the basis for larger paintings.

However, on larger-scale canvases, I found that I struggled to replicate the energetic brushwork of the smaller studies and, as a result, my work has stayed at a smaller scale. My painting has also been manipulated by a new mark-making tool - my painting wedge. This tool has two hard edges and fits neatly in the palm of the hand. I use it alongside a variety of filbert brushes, and sometimes an etching needle used to score the surface with a sgraffito effect. With these processes combined, I have begun to produce my 'signature' style of painting.

Working small also lends itself well to building up a whole series of artworks that relate to each other in terms of their origins. Using oils means that drying time can sometimes be a problem, but by working with thin layers and diluting the paint with small amounts of turpentine, and by working on up to ten pieces at once, I have developed a way of working that has enabled these paintings not only to share the same subject matter, but also to share the same history in terms of their colour palette, mark-making and general process.

After art school, I continued to develop my artistic process while making the most of the facilities available to me. Having only a small garden shed as a studio, I retained the small scale of my paintings while looking to push and pull the boundaries between abstraction and figuration. I also began to work full time as a secondary school art teacher, which broadened my horizons when it came to exploring and experimenting with other working methods. 


\section{THE BIG OPPORTUNITY}

In 2017 my work was selected for an national landscape painting competition that was also shown as part of a television series on the UK digital platform, Sky Arts. Landscape Artist of the Year was formatted so that I would be competing against other artists, both professional and amateur, who would be rendering a given scene in a limited time of four hours. My practice lent itself well to these constraints, and I worked on four studies at once, developing the more successful pieces until I was left with two to choose from at the end. I made my way through the competition and eventually won the final. The prize was a $£ 10,000$ commission to paint the house that had once belonged to the famous British playwright Noël Coward in Jamaica.

The unprecedented publicity that came with winning the competition allowed my work to be seen by a large audience across the world. I was approached by art galleries and collectors, taking my art practice overnight from being a part-time, out-of-hours occupation to a totally different place. 2018 proved to be a life-changing year for me as an emerging artist. I had a small solo show in February that featured most of my recent work, including paintings completed on location in Jamaica and those from the Landscape Artist of the Year series. This exhibition was incredibly successful, and I later had a second exhibition in Nottingham.

I wanted to make the most of the opportunity I had been given while also continuing to develop my artistic practice. As a result, I began looking into art residencies in order to find ways in which I could become more focused on my work, but also develop professionally by meeting other artists. Combining teaching with my artistic practice is also something that I wanted to continue.

\section{INTRANSIT}

Bags packed, I started on my journey from the UK to Canada, where I travelled from Calgary to Vancouver through the Canadian Rockies. When travelling, I found that the contrast in the light between the sun casting shadows on the mountains and the linear shadows of the power lines on the roads was visually attractive in terms of composition. In fact, compositionally, Canada lent itself perfectly to my work. The long straight roads leading the eye away to a distant point were complemented by the flash of yellow from the central double lines, while in the towns, the graphic quality of power lines combined with railway lines, or broken up by manmade objects, inspired my work. I began to document my journey with drawings and sketchbook studies supported by photographs. However, forest fires often caused the light to become diffused and flat, so I had to decide whether to depict the landscape as it was or to use my artistic licence to create a more enticing study.

After experiencing the sights and sounds of Vancouver, I travelled to Victoria on Vancouver Island to give a talk to the Victoria Arts Society. Following this, I made my way down to San Francisco via Seattle, all the time making drawing and colour studies and visiting numerous galleries and museums.

San Francisco in particular became an artistic pilgrimage for me. As the location for much of Diebenkorn's shown work in MOMA, and for his practice, I found myself enticed by every view, especially the lofty streets and crystalclear light.Wayne Thiebauld, another artist whose work also plays with the urban landscape, and who aligned himself with Diebenkorn and the Bay Area Figurative Movement, also featured in many of the city's galleries. I later went on to begin a body of work influenced by my time in this part of California, work that is still in progress.

Eventually, after a short stopover in Fiji, I arrived in New Zealand. 


\section{DUNEDIN}

My residency at the Dunedin School of Art began on day one with introductions to the various members of the department, and then setting up my temporary work space in the school's new $\bigcirc$ Block. Fantastic light bathed the 'studio,' and lots of working space was made available as many students had started their exams. With the aid of the technicians, I cut up pieces of MDF into boards and prepared them with fourtimes primed gesso. I had plenty of boards to prepare, a task that was made much easier by the use of the departmental workshop and its circular saw - thanks to technician Colin Howes.

Once sanded and made smooth, the boards were ready for painting. In the meantime I explored the city - most days were bathed in beautiful spring light that made for excellent compositions. For the first few days, I divided my time between drawing in the long shadows cast by the morning and evening light and painting in the studio at midday and during the evenings. Adapting to a new space takes time, especially when a large body of primary work (drawings, photographs and written work) has been collected - then the time arrives to transcribe them into 'finished' paintings. Suddenly I felt under an immense amount of pressure to 'produce.' Fortunately for me, my style lends itself to work on large bodies of work simultaneously and at speed, but I failed to take account of the mental health problems that I would face during the residency.

With only five weeks in the space, I was acutely aware that "every minute counted." Having enjoyed the luxury of time in the past, and then facing the reality of managing my creative time with jobs and other 'real life' commitments, to have the luxury of five weeks dedicated to my work was slightly overwhelming. Over the first two weeks I did manage to overcome this self-imposed stress by giving myself time to step away, read, spend time outside and, most importantly, speak to other artists and practitioners within the department. This is a huge part of doing an art residency and is one of the biggest benefits of becoming part of a group of fellow artists, even if it is only for a short time. The Masters students in particular were very useful to talk to and discuss practical problems with, as were the painting tutors and technicians. I was able to deliver a short presentation and a practical workshop related my process, which also opened up discussions and questions. This also allowed me to reflect on my own artistic process. 


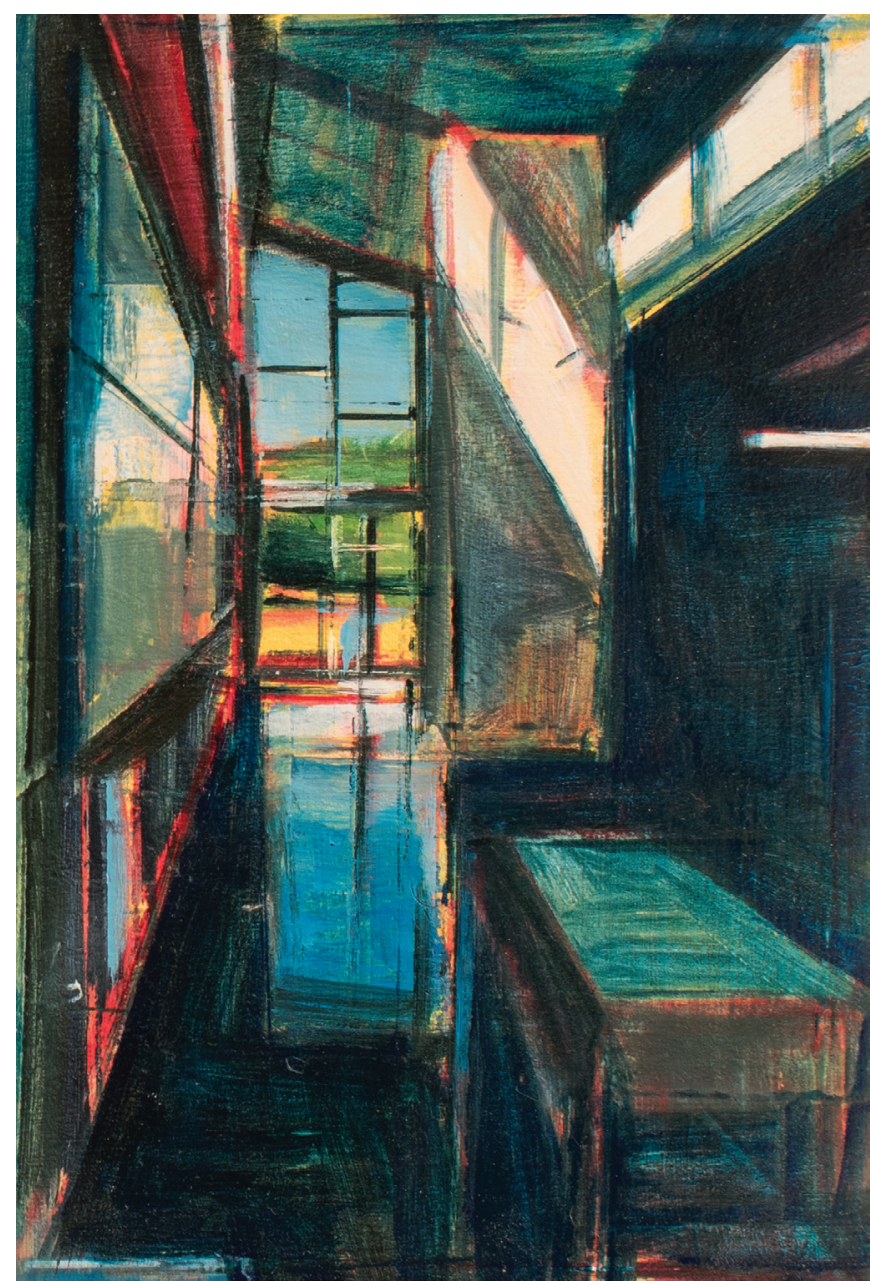

Figure 5. Tom Voyce, Art School Interior, 2018, oil on board, $21 \times 14 \mathrm{~cm}$.
During my time in Dunedin my work developed in unexpected ways. A discussion with a technician regarding surfaces enabled me to experiment with aluminium, a material used by many students within the department. After being sanded and primed, the surface performs as well as the familiar MDF board and is superior in the long term (MDF degrades over time if primed incorrectly and can be easily damaged in damp conditions). I also began to treat my surfaces more rigorously with sealer and gesso as a result of these technical conversations.

Changes in my painting process also began to take place during my residency at the school of art. I was keen to use the time to experiment not only with surfaces, but also with techniques and palette choice. When 'sketching out' and underpainting during the first stage of a painting, I had always used a traditional, darker colour such as a sienna, umber or phthalo blue. After conversations with painting students and with technician/artist Steev Peyroux, I played around with some livelier colours, settling on a cadmium red. This base layer continues to

show through as my work builds up - I feel that these bright colours really make the overall image 'pop'.

Over the weeks, a body of work started to come together, taken from drawings and images of Dunedin and Otago. By working on many works at once, sometimes ten at a time, I attempted to rotate each artwork using the same palette and marks so that the paintings have a shared history. I find this approach is beneficial when a body of works explores the same place or location. This process also allows me to be less attached to a piece of work, enabling more risks to be taken, with a sense of energy in the brushwork. Dunedin seemed somehow familiar to me - the architecture, the streets and surroundings - perhaps reflecting the town's Scottish/ British foundations.

I was also keen to make the most of my time by drawing and taking photographs of places around me. I made a short trip south to Invercargill and on into Central Otago where the flat, barren landscape reminded me much of the work of Edward Hopper - but of course this place is intriniscally linked to the native-born Graham Sydney, whose inspiration seemed to be on show everywhere! 
It was here too that I began to explore the use of strong perspective in almost every piece that I was producing. The long straight roads that recede into the distance draw the eye; they suggest movement or perhaps 'transit.' My aim was to still maintain a sense of the abstract, so working within areas of little or no detail allowed my frantic brushstrokes and the layering of colours to create interest in the ordinary. I also had one eye on the compositional elements that made Richard Diebenkorn's work so successful. The Ocean Park works, despite being non-figurative, are all about place and somehow they capture that. The way I divide up a composition - with vertical and horizontal lines rendered from shadows, pavements, buildings or even brushstrokes or marks - are a nod to this way of working.

During my final few days in Dunedin I began to 'resolve' a number of works that I felt were successful, but regrettably there are always works that don't make the grade for one reason or another. As a result of of my working process I have allowed for this, and indeed I want this to happen. It is a learning process, and my hope is that I can build on the positive elements in successful works to make stronger paintings. Experimental pieces often fail. This was the case with some of my larger pieces, where the brushes that I had available were poor substitutes for those that had proved so effective on a smaller scale - these works were less lively, more 'tight' and lacked much of the energy seen in the smaller pieces.

I learned a lot during my short stay at the art school. Adapting to the space available and working as a disciplined, full-time artist is surprisingly challenging and, despite having the luxurious freedom to experiment and develop, the pressure that came from within was certainly something that I didn't anticipate. Working with the amazing staff and students at the Dunedin School of Art was a great experience - something that an artist lacks when painting alone in a studio. It was great being part of a creative community and I feel that this is one of the major lessons that I will take away from my time there.

Art residencies can be a very rewarding and rich experience and can teach you a lot about yourself as an artist. I can thoroughly recommend anyone who is interested in this creative challenge to give it a go, especially at the Dunedin School of Art. My thanks go to the staff and students at for their friendliness and support during my short stay. 
Tom Voyce is a British artist and teacher based in the UK. He received a Master of Fine Arts from Aberystwyth University School of Art. Tom won the Sky Arts Landscape Artist of the Year competition in 20 I7, which was also made into a television series that was screened around the world. He has completed residencies at the Ecologica Artist Residency, Andalucía, Spain; Corban Estates in Auckland; and the Caselberg Trust, Dunedin. He is represented by two galleries in the UK and The Artist's Room in Dunedin.

I Edward Hopper, Gas, 1940, oil on board, 66.7 × 102.2 cm. MOMA, New York. Image: https://www.moma.org/collection/ works/80000.

2 Henri Matisse, French Window at Collioure, 1914, oil on canvas, I 6.5 ×88 cm. Musée National d'Art Moderne, Paris. Image: https://curiator.com/art/henri-matisse/french-window-at-collioure.

3 J Baal-Teshuva, Rothko (New York: Taschen, 2013), 24.

4 David A Ross, "Foreword," in J Livingston, The Art of Richard Diebenkorn (New York: Whitney Museum of Modern Art, 1997), II.

5 Livingston, The Art of Richard Diebenkorn, 17.

6 Ibid.

7 Ibid., 62.

8 Richard Diebenkorn, Ocean Park \#79, 1975, oil on canvas, $236.2 \times 205.7 \mathrm{~cm}$. Modern Art Museum of Fort Worth. Image: https://www.themodern.org/ocean-park-79.

9 RichardDiebenkorn,Cityscape I, 1963,oiloncanvas, I 53.4× 128.3cm.SanFrancisco MuseumofModernArt(SFMOMA),SanFrancisco. Image: https://collection.diebenkorn.org/objects/378/cityscape- l?ctx=3d5d6342-d7f7-43 I 0-9396-cb2d49727a3c\&idx=2.

10 WWells, Silent Theatre: The Art of Edward Hopper (London: Phaidon, 2008), 10. 